\title{
THE LONG TERM RESULTS OF TRANSURETHRAL DIVISION OF THE EXTERNAL URETHRAL SPHINCTER IN THE NEUROPATHIC URETHRA WITH REFERENCE TO POTENCY
}

\author{
By R. M. JAMESON, F.R.C.S. \\ Royal Liverpool Hospital \& Regional Spinal Injuries Centre, Southport, England.
}

\begin{abstract}
This paper reviews the 900 patients admitted to the Regional Paraplegic Centre in Liverpool from I956 to I980. The operation of division of the external sphincter, first described by Cosbie Ross in 1956, was found to be indicated in I 43 of these patients with neuropathic outflow obstruction, and there was no postoperative impotence.
\end{abstract}

Key words: The neuropathic urethra; Transurethral division of the external urethral sphincter; potency.

\section{Introduction}

ENDOSCOPIC division of the external sphincter (internal membranous urethrotomy) was described by Cosbie Ross for the relief of outflow obstruction in the neuropathic bladder (Ross et al., 1958 following the observations of Emmett, I948). Previous attempts to relieve obstruction demonstrated at the level of the external sphincter by ascending and descending cystourethrography had been by division of the pudendal nerve at the ischium. However this operation was not always successful and was found to cause impotence (Ross and Damanski, I953). Therefore an endoscopic approach was devised and the value of the procedure has been amply demonstrated not only by successive reviews of the operation by its developers (Ross, Gibbon and Damanski, I957; 1958) and (Ross, Gibbon and Sham Sunder, I976) but by the acceptance world-wide of the procedure (Schellhammer et al., 1974; Leriche et al., I979, Hachen et al., I976). From 1956 to 1980 322 patients have needed division of the external sphincter for relief of urinary obstruction; some have had the operation repeated. In the early reports at 10 and 20 year follow-up there was no mention of impotence as a complication of the operation. In recent years reports of post-operative impotence, sometimes transient, have been published (Thomas, I 976; Crane and Hackler, 1976; Schoenfield et al., 1974). Therefore this prospective study of I 43 men undergoing division of the external urethral sphincter was undertaken in the years $1975-80$.

\section{Materials and Methods}

This is a prospective study involving I 43 men. The incidence of potency was noted before and after operation. Potency is defined as the ability to get and maintain an erect penis during intercourse. As in previous studies from the Southport Spinal Injuries Centre the effect of the operation on upper urinary tract dilatation and the combination with internal membranous urethrotomy with other procedures were recorded. 


\section{Results}

The analysis of the I 43 operations is shown in Table I and the level of the spinal lesion in Table II, most if not all of the neurological lesions were complete. Note that internal urethrotomy had to be repeated in 12 men because of incomplete relief of obstruction but continence was preserved after two operations in all these 12 patients. Preservation of continence whenever possible is helpful for not all paraplegics are confined to a chair; many are fully employed and active. The operation can be safely combined with resection of the bladder neck tissue or prostate. When the renal tract is dilated the operation will improve drainage (Table III).

\section{TABLE I}

Analysis of Transurethral Operations 1975-1980

\begin{tabular}{lr}
\hline D.E.S. performed once & 106 \\
Repeated D.E.S. & I2 \\
D.E.S. combined with TURBN & 25 \\
Total I43 Operations & \\
\hline
\end{tabular}

\section{TABLE II}

Nearly all these patients had complete lesions

Level of Spinal Lesion in D.E.S. 1975-1980 Series

\begin{tabular}{cc}
\hline Cervical & 65 \\
Thoracic & 70 \\
Lumbar & 8
\end{tabular}

Note no detrusor reflex contraction in 47 cases.

TABLE III

Effect of D.E.S. on Upper Tract Obstruction in I 43 Cases 1975-I980 Series

Hydronephrosis present before operation

Disappeared after D.E.S.

Unchanged

Improved
20 cases

9 cases

5 cases

6 cases

None made worse after D.E.S.

In the 20 year survey (Ross et al., I976) 33 men were impotent after onset of the paraplegia. There was no detailed record of the sexual function in another $5 \mathrm{I}$ cases. In this study 52 were impotent before the operation, 90 were potent without any deterioration in sexual function after sphincter 
division. In only one case was there no record of sexual function. The safety of division of the external urethral sphincter is confirmed in this and our earlier reports. (Abel et al., I974) (Gibbon et al., I965, I967 and I976). There was no mortality in this series. In men with long-standing renal damage the risk of chronic renal failure with amyloid disease has been well recognised; there were 12 late deaths, all after 3 years since operation. In these cases with renal failure and amyloid disease all had severe hydronephrosis, pyelonephritic scarring and persistent bacteriuria.

\section{Discussion}

It is the state of the urinary tract that largely determines the long term prognosis in the paraplegic but the quality of life also depends upon the amount of rehabilitation. Rehabilitation begins from the time of injury and includes not only self-care but mobility and the learning of new skills as well as restoration of dignity and self-respect. Adjustment of relationships within the family and a recognition of the sexual needs has led to the development of better methods of relieving urinary obstruction and preserving potency. Pudendal neurectomy was found to cause impotence in 60 per cent cases and so was discontinued (Ross and Damanski, I953). At first the sphincter was resected with the cold punch, this technique being abandoned because of haemorrhage. The technique used is to tease apart the fibres laterally of the external sphincter at the level of the verumontanum using a coagulating current at low power and a diathermy ball or Colling's type of knife. We do not use a loop resectoscope electrode. The technique has been described in our reports (Gibbon, 1973). The effectiveness of the procedure upon the urethral pressure profile has been fully documented (Abel et al., 1975). Crane and Hackler (1976) were unable to draw any conclusions about the incidence of the effect of the operation upon erections but laid stress on the value of incisions laterally at sphincter level. Dollfus and his colleagues (1976) used a cutting loop and noted severe bleeding in some men; transient impotence was found in one case who needed diathermy coagulation to stop bleeding. It was believed that the diathermy coagulation may have caused the impotence. Schoenfield (I974) suggested that vascular damage to the corpus spongiosum by diathermy may cause impotence. Schellhammer (I974) advised the avoidance of the diathermy loop and there is no record of impotence in his series of I 50 cases.

Thomas in 1976 drew attention to the sexual function and endoscopic surgery. In his series of 56 men I 3 were impotent before operation (23 per cent). No change was found in 19 men ( 44 per cent) but 24 cases had transient or permanent effects on potency after division of the external sphincter. Perhaps the division was deep and a cutting current used, possibly a loop was used for the division. Nevertheless his figures stand. He wisely drew attention to the psychological factors, as did Sir Ludwig Guttmann in the discussion that followed (1976). Windle and Roberts (I974) observed that seven out of 49 non-paraplegic men became impotent after transurethral surgery. In their control group five out of 90 became impotent after various groin, scrotal and intraperitoneal operations. In my series of $\mathrm{I} 600$ prostatectomies in non-paraplegics 4 per cent became impotent after prostatectomy. Incidentally 70 per cent of these men who were aged over 70 years of age were potent (Jameson I98I). 
In only six patients we have performed a loop resection of the bladder neck and sphincter tissue to obtain tissue for histological study. The findings relating to the nervous innervation and muscle properties of the external sphincter have been reported by Gosling and Dixon (I979). Others have used a loop electrode for the operation without impotence (Madersbacher and Scott, I976). Whatever the choice of operative technique (and we prefer the lateral incisions) we advise a technique which does not encroach into the venous sinuses and cause bleeding. Coagulation, if heavy, is most likely to be a local factor leading to impotence. A comparison is the incidence of impotence and deformity in Peyronie's disease which can be shown to reduce the available vascular space in the erectile tissue (Gelbard et al., I98I). There has been no documented case of impotence whether transient or permanent in this prospective study of I 43 operations, nor in any of the 322 cases treated from 1956 to I 980.

\section{SUMMARY}

The operation of endoscopic biopsy of the external urethral (internal membranous urethrotomy) was first used in England in 1957. Currently the total of 322 patients had this operation for relief of outflow tract obstruction in the neuropathic bladder. In recent years reports of post-operative impotence had appeared in the literature. This is a prospective study of I 43 men undergoing division of the external urethral sphincter to determine if there was any effect on sexual function as well as assessing again the long term results of the operation.

There has been no case of impotence in this prospective study of 143 patients, nor has it been documented in any of the 322 cases treated from I 956 to I980.

This brief study confirms previous reports on the reliability and simplicity of the operation.

\section{RÉSUMÉ}

La biopsie endoscopique du sphincter externe urétral (urétrotomie membraneuse interne) se pratique en Angleterre depuis I957. Jusqu'à présent, la totalité des 322 opérés ont subi l'intervention pour soulagement de la voie d'évacuation de la vessie neuropathique. Depuis peu, les revues medicales ont signalé un certain nombre de cas d'impuissance post-opératoire. La présente étude, d'ordre prospectif, se propose de suivre I 43 malades, opérés par division du sphincter externe urétral, dans le but de déterminer, le cas échéant, son effet sur la fonction sexuelle et, éventuellement, de remettre à jour les résultats à long terme du procédé.

Aucun cas d'impuissance parmi ces I43 opérés n'a été enregistré; de même parmi les 322 opérés du groupe traité entre 1956 et 1980.

Cette courte étude sait donc confirmer des rapports antérieurs quant à l'efficacité et à la simplicité de l'intervention.

\section{ZUSAMMENFASSUNG}

I 957 wurde zum ersten $\mathrm{Mal}$ in England die endoskopische Biopsie des äusseren Urethralsphincters (innere Membranurethrotomie) durchgeführt. Bisher wurde an insgesamt 322 Patienten, die an einer neuropathischen Harnblase erkrankt waren, diese Operation durchgeführt, mit dem Ziel die Obstruktion zu beseitigen und den Urinfluss zu verbessern.

In den letzten Jahren wurde in der Literatur berichtet, dass postoperativ Impotenz aufgetreten war. In dieser hier vorgestellten prospektiven Studie, wurde an I 43 Männern 
eine Spaltung des äusseren Urethralsphincters durchgeführt. Die Untersuchung sollte einmal klären, ob eine Beeinflussung der Sexualfunktion postoperativ auftritt, zum anderen hatte sie zum Ziel prospektiv das Operationsergebnis zu beurteilen.

In keinem Fall trat postoperativ eine Impotenz auf, noch wurde im Zeitraum zwischen 1956-1980 bei 322 Fällen eine Impotenz festgestellt.

Diese kurze Studie unterstreicht vorangeganene Berichte, dass die Operation zuverlässig und einfach durchzuführen ist.

\section{REFERENCES}

Abel, B. J., Gibbon, N. O. K., Jameson, R. M. \& Ross J. C. (I975). Urethral pressure profile after division of the external sphincter. Paraplegia, 13, 37-4I.

ABel, B. J., GibBon, N. O. K., Jameson, R. M. \& KRishnaN, K. R. (1974). 'The neuropathic urethra'. Lancet, 2, I229-1230.

Crane, D. B. \& HACKLER, R. H. (I976). 'External Sphincterotomy: Its effect on erections'. F. Urol., I16, 316-319.

Dollfus, P. Jurascheck, F., Adli, G. \& Chapuis, A. (1976). 'Impairment of erection after External Sphincter Resection'. Paraplegia, 13, 290-293.

Emmett, J. L., Daut, R. V., DunN, L. H. (1948). Role of External Sphincter in the normal bladder and the cord bladder. F. Urol., 59, 439-454.

Gelbard, M. Sarte, D. \& Kaufman, J. J. (I98I). Ultrasound Imaging of Peyronie's Plaques. F. Urol., 125, 44-46.

Gibbon, N. O. K., Ross, J. C. \& Damanski, M. (1965). Bladder neck resection in the paraplegic - report of over 100 cases. Int. F. Paraplegia, 2, 264-278.

Gibbon, N. O. K. (1973). Division of the external sphincter. Brit. F. Urol., 45, I Io-I I 5.

Gibbon, N. O. K. (1976). A Further look at the rationale of External Sphincterotomy. Paraplegia, 13, 243-246.

Gosling, J. A. \& Dixon, J. S. (1979). F. of Anatomy, 129, 216-220.

Guttman, Sir L. (1976). Paraplegia, 13, 294.

HACHEN, H. J. \& OTT, R. (1976). Late results of bilateral endoscopic sphincterotomy in patients with upper motor neurone lesions. Paraplegia, 13, 268-274.

Jameson, R. M. (198I). Prophecy and Prostatectomy. Practitioner, 225, 56I-565.

Leriche, A., ArChimbaud, J. P., Berard, E., Minaire, P. \& Bourret, J. (I979). Differential diagnosis and limitations of external sphincterotomy. Paraplegia, 13, 280-285.

Madersbacher, H. \& Brantley Scott, F. (1976). The Twelve O'Clock sphincterotomy: technique, indications and results. Paraplegia, 13, 26I-267.

Ross, J. C. (1965). Treatment of the Bladder in Paraplegia. Brit. F. Urol., 28, 14-23.

Ross, J. C. \& Damanski, M. (I953). Pudendal Neurectomy in the Treatment of the Bladder in Spinal Injury. Brit. $\mathcal{F}$. Urol., 25, 45-48.

Ross, J. C., Gibbon, N. O. K., Damanski, M. (1958). Division of the External Sphincter in the treatment of the paraplegic bladder. Brit. F. Urol., 30, 204-2 I 2.

Ross, J. C., Gibbon, N. O. K. \& Damanski, M. (I967). Division of the External Sphincter in the treatment of the neuropathic bladder: Io year review. Brit. F. Surgery, 54, 627628.

Ross, J. C., Gibbon, N. O. K. \& Sham Sunder, G. (1976). Division of the External Sphincter in the neuropathic bladder: 20 year review. Brit. F. Urol., 48, 649-656.

Schellhammer, P. F., Hackler, R. H. \& Bunts, R. C. (1974). External Sphincterotomy: rationale for the procedure and experiences with is 50 patients. Paraplegia, I, 5-I4.

Schoenfield, L., Carrion, H. M. \& Politano, V. A. (I974). Erectile impotence: complication of external sphincterotomy. Urology, 4, 68I-683.

Thomas, D. G. (1976). The effect of transurethral surgery on penile erections in spinal cord injury patients. Paraplegia, 13, 286-289.

WindLE, R. \& ROBERTS, J. B. (1974). Ejaculatory function after prostatectomy. Prac. Royal Society of Medicine, 67, I I60-I I62. 